\title{
Mobilization, Isolation and Characterization of Stem Cells from Peripheral Blood: a Systematic Review
}

\author{
Natali Yosupov ${ }^{1}$, Haim Haimov ${ }^{1}$, Gintaras Juodzbalys ${ }^{1}$ \\ ${ }^{1}$ Department of Oral and Maxillofacial Surgery, Lithuanian University of Health Sciences, Kaunas, Lithuania.
}

\author{
Corresponding Author: \\ Natali Yosupov \\ Bar Ilan 17-4, Bat Yam, 5958135 \\ Israel \\ Phone: +972524622975 \\ Fax: 03-5533061 \\ E-mail: natali0230@walla.com
}

\begin{abstract}
Objectives: The purpose of this article is to systematically review the methods of mobilization, isolation and characterization of stem cells from peripheral blood and to discuss their potential therapeutic applications for bone tissue regeneration.

Material and Methods: An electronic literature search was performed through MEDLINE (PubMed) electronic database. The search was restricted to English language articles published during the last 10 years, from January 2006 to November 2016.

Results: In total, 37 literature sources were reviewed, and 11 of the most relevant articles that are suitable to the criteria were selected. Articles were analysed with data on animals and humans for mobilization, isolation and characterization of stem cells from peripheral blood. From the examination of selected articles, the mobilization materials, side effects, alternatives and factors affecting the extracted amount of mesenchymal stem cells (MSC) from mobilized peripheral blood of healthy individuals, as well as characterization of mobilized MSC were reviewed in this article.

Conclusions: Bone tissue engineering is a potential alternative strategy in bone regeneration and bone defect repair, however, insufficiency data display in the literature on potential therapeutic applications of peripheral blood stem cells for bone tissue regeneration.
\end{abstract}

Keywords: blood; bone regeneration; cell isolation; hematopoietic stem cell mobilization; peripheral blood stem cells.

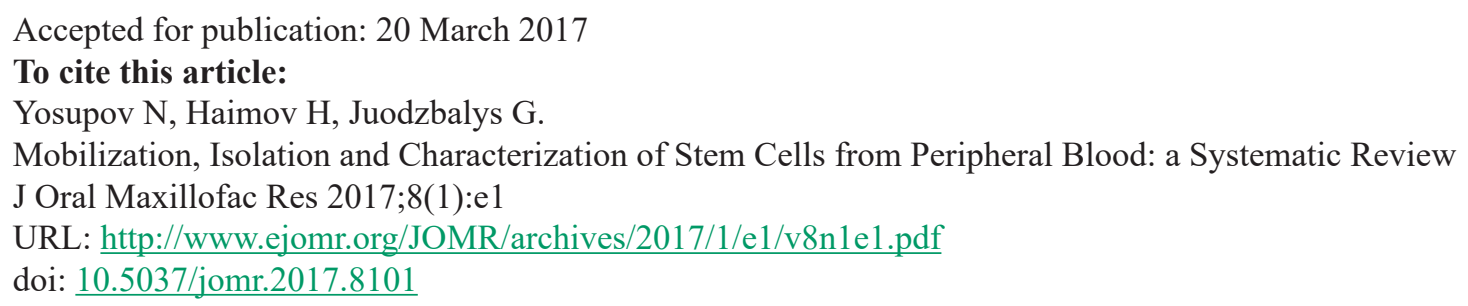




\section{INTRODUCTION}

Bone tissue is capable of spontaneous self-repair, however, this capacity may be impaired due to the size of the defect andlor the presence of certain diseases [1, $\underline{2}$. Although autogenous bone graft considered the gold standard for reconstruction of large skeletal defects, the application of this technique is hampered by the risks for infection, rejection and complications due to additional surgical procedures which requires harvest bone material, consequent donor site morbidity, limited supply of autogenous bone graft, and high cost which have fuelled the search for alternative approach to repair large skeletal defects [1-3]. Bone tissue engineering is an alternative strategy that fills the clinical need for autologous bone transplantation [1].

Scientists have discovered a wide array of stem cells that have unique capabilities to self-renew, to grow indefinitely, and to develop into multiple cell types and tissues [4]. Postnatal skeletal stem and progenitor cells differentiate into a multitude of specialized cells that participate directly in bone regeneration [1] which is a dynamic process that balances the breaking down of old bone, the generation of new bone, and the infiltration of these areas with blood vessels [4]. Two broad categories of cell populations available for bone regeneration include osteoblasts and multipotent cells. Osteoblasts possessing a limited number of divisions, and readily form mineralized matrix and multipotent stem cells have the ability for prolonged division while maintaining the capacity to differentiate along multiple lineages [2] and to improve bone regeneration in large bone defects in animal models []․ By that considerable attention has received to the use of autologous or allogeneic adult stem cells for tissue repair in humans [] $]$.

Mononuclear cells (MNCs) from bone marrow (BM) contain hematopoietic stem/progenitor cells (HSPCs), mesenchymal/nonhaematopoietic stem cells (MSCs), endothelial progenitor cells (EPCs), and very small embryonic like stem cells (VSELs) $[\underline{7}, \underline{8}]$.

HSPCs capable of differentiating into all the blood cell types [7], and MSCs are morphologically fibroblast-like cells that characterized by their ability to self-renew, to produce cytokines or growth factors and their capacity to undergo trilineage differentiation into tissues of mesodermal origin (osteoblasts, adipocytes, chondrocytes and myocytes) $[\underline{9}, \underline{10}]$. Additionally, according to the International Society for Cellular Therapy (ISCT), these cells identified based on their adherence to plastic for proliferation $[\underline{7}, \underline{11}]$ and express several stem cell-associated surface markers [12]. MSCs indicates cellular pluripotency and suggests to be responsible for the normal turnover and differentiation toward adult mesenchyme tissues [9].

MSCs have been isolated from a range of tissues, including BM, adipose tissue, foetal tissue, placenta, umbilical cord and etc. Despite the remarkably high percentage of MSCs, BM and adipose tissue harvesting process is invasive, traumatic, and the amount of material extracted is limited and requires anaesthesia $[\underline{10}, \underline{12}]$.

Foetal tissues, placenta and umbilical cord are potentially attractive sources of MSCs, since they contain abundant MSCs and can be collected without the requirement for invasive methods, but are not always available when needed [12]. Therefore, exploring new sources and isolation techniques for obtaining such cells is of great interest [10].

Due to the fact that BM derived stem cells circulate in peripheral blood $(\mathrm{PB})$ at a very low level under steady-state conditions, it is necessary to mobilize HSPCs from BM to PB $[\underline{8}, \underline{13}]$.

Mobilization, which defines as forced egress of stem/ progenitor cells from their niche(s) primarily in $\mathrm{BM}$, to the PB [6], achieved by the administration of cytokines such as granulocyte-colonystimulating factor (G-CSF, filgrastim, lenograstim, pegfilgrastim) or plerixafor which can be used alone or in combination with G-CSF for normal donors who failed to mobilize enough stem cells with G-CSF [14]. The strategy of purposefully mobilizing stem cells began with the original observation that chemotherapy increases circulating CD34+ cells (a marker for HSCs and progenitor cells) [6]. A dose of $2 \times 10^{6} \mathrm{CD} 34+$ cells $/ \mathrm{kg}$ body weight is generally considered the minimum required to achieve durable engraftment, higher dose as $4 \times 10^{6}$ to $6 \times 10^{6} \mathrm{CD} 34+$ cells $/ \mathrm{kg}$ has been associated with faster hematopoietic recovery, better survival rates, and lower resource utilization in some studies [14].

Specific monoclonal antibodies react with molecules on specific cell surfaces in purpose to identify cluster differentiation (CD) for the markers which can facilitate the identification, isolation, and study of stem cells. Multiple surface markers have been associated with MSCs, including CD29, CD34, CD106, CD105, CD133, CD166, and CD309, however, the receptor proteins differentiated osteogenic cells, have not yet been conclusively mapped [4].

MNCs isolated from PB are a heterogeneous mixture of HSPCs and MSCs, and by immunophenotyping it is possible to distinguish between those 2 populations. The CD34+ and CD45+ cells represent the HSPCs, 
do not adhere in specific culture conditions and hence, do not survive. In contrast, CD90-, CD51- and CD105- are positive cells represent MSCs, which adhere and proliferate in the given culture conditions and hence, are present in both the fresh and the expanded samples []].

Albeit CD90 is a small glycophosphatidylinositolanchored protein that is found in low numbers in PB. Its expression is an evident that MSCs can be obtained from $\mathrm{PB}$, if their circulating concentrations can be increased by experimental or physiological manipulations, consequently peripheral blood could be a valuable source for cell-based therapies [7].

Since collection of blood samples is minimally invasive, PB may be a source of progenitor cells in clinical situations [12].

Consequently, the purpose of this article is to systematically review the methods of mobilization, isolation and characterization of stem cells from peripheral blood and to discuss their potential therapeutic applications for bone tissue regeneration.

\section{MATERIAL AND METHODS \\ Protocol and registration}

The methods of the analysis and inclusion criteria were specified in advance and documented in a protocol. The review was registered in PROSPERO, an international prospective register of systematic reviews [15]. The protocol registration number: CRD42016051837, can be accessed through the following link:

http://www.crd.york.ac.uk/PROSPERO/display record.asp?ID $=$ CRD42016051837

\section{Focus questions}

The aim of this review is to find answers from the data extracted from the current literature to the following questions:

1. What kind of side effects can occur after administration of mobilization material of MSCs to a healthy person? Any alternatives?

2. Is the mobilized MSCs have the same characterization as purposed by ISCT?

3. Does mobilization procedure affected by donor's age?

\section{Types of publication}

The review included studies in vivo published in the English language.

\section{Types of studies}

The review included laboratory research studies, in vitro and in vitro studies that using cells from human or animals, single case reports were excluded.

\section{Information sources}

The information source was the MEDLINE (PubMed) database.

\section{Population}

Studies of human and animals that undergo mobilization treatment and isolation of MSCs from PB. Treatment had to be completed on healthy animals and humans without systemic diseases and oncological disorders.

\section{Literature search strategy}

According to the PRISMA guidelines [16], an electronic search was conducted using MEDLINE (PubMed) to locate articles concerning methods of mobilization and isolation of MSCs from PB and their potential for bone tissue regeneration.

The keywords used in the search of the selected electronic databases included the following: ("bone regeneration") and ((("peripheral blood stem cells") OR "stem cells") OR "mobilization") OR "isolation"). The search was restricted to English language articles published from January 2006 to November 2016.

Flow diagram of studies selection according PRISMA guidelines (Figure 1).

\section{Inclusion and exclusion criteria}

The full text of all studies of possible relevance was obtained for assessment against the following inclusion criteria:

- Mobilization, isolation and characterization of stem cells from peripheral blood had to be completed on healthy animals and humans without systemic diseases and/or oncological disorders.

- Clinical articles on experimental model.

- Studying involving at least 5 models investigated (if less so statistically irrelevant).

- Same osteopotential cells differentiation.

\section{Exclusion criteria for the selection}

- Patients undergoing chemotherapy (cancer patients). 


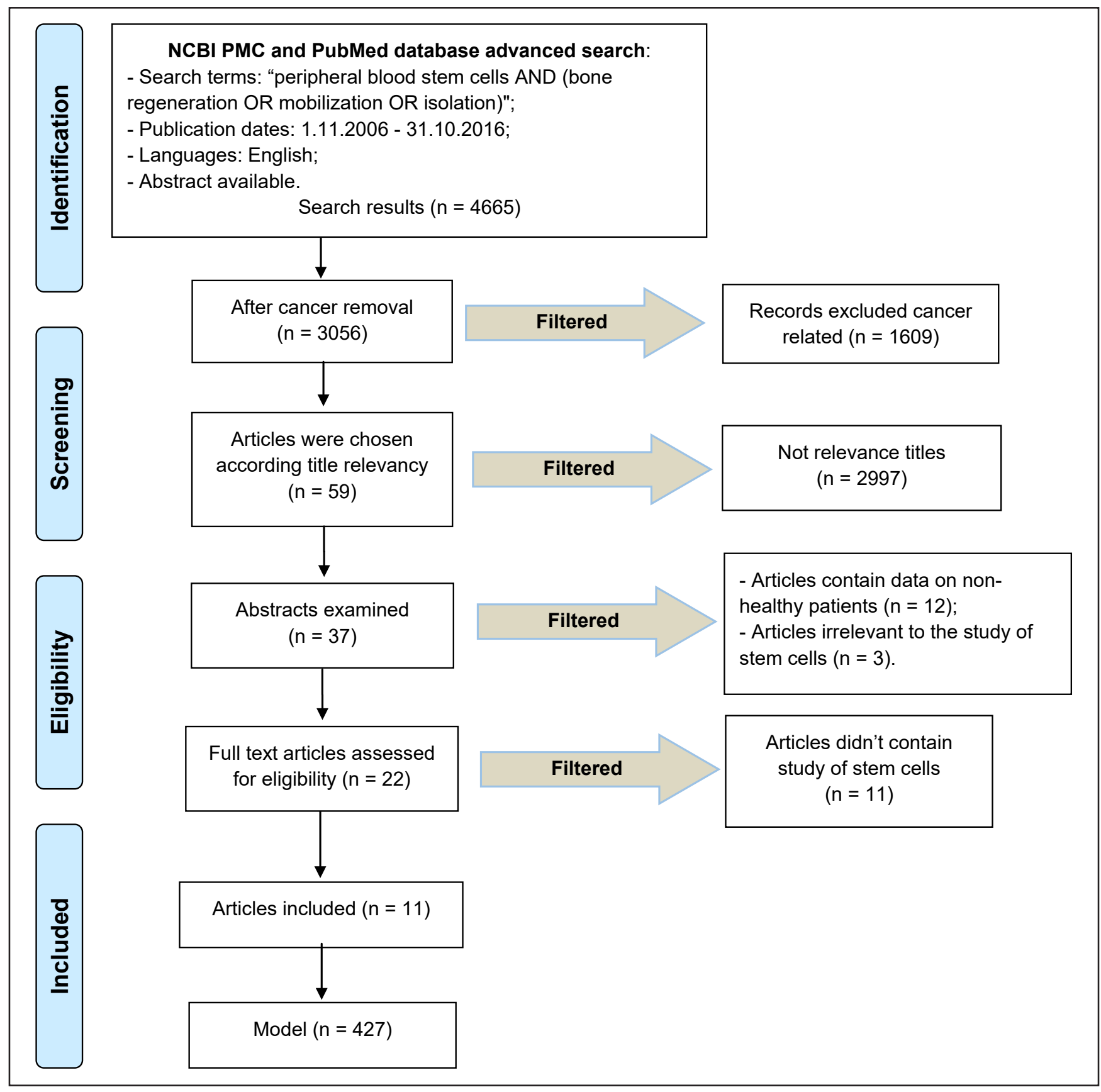

Figure 1. PRISMA flow diagram.

- Articles irrelevant to the study of stem cells mobilization, harvesting and bone regeneration.

- Not enough information regarding the selected topic.

- Studies that included unclear data, with authors who could not be contacted for any reason.

\section{Sequential search strategy}

The resulting articles were independently subjected to clear inclusion and exclusion criteria by 2 reviewers as follows. In conflict cases the reviewers resolved differences through discussion, consulting a third party when consensus could not be reached.
The third party was an experienced senior reviewer. Following the initial literature search, all article titles were screened to eliminate irrelevant publications, considering the exclusion criteria. Next, studies were excluded based on data obtained from screening the abstracts. The final stage of screening involved reading the full texts to confirm each study's eligibility, based on the inclusion criteria.

\section{Data extraction}

The data were independently extracted from studies in the form of variables, according to the aims and themes of the present review, as listed onwards. 


\section{Data items}

Data were collected from the included articles and arranged in the following fields:

- "Author (year)" - revealed the author and year of publication.

- "Type of study" - indicated the type of the study.

- "Model investigated"- indicates the model which was examined.

- "Sample size" - described the number of patients examined.

- "Cell source" - describes the tissue MSCs have been isolated from.

- "mobilization procedure and material"- indicates if any material $\backslash$ method was used in order to mobilize stem cells.

- "Assay of mobilization" - methods which evaluate the amount of mobilized cells.

- "Apheresis procedure and method"- indicates if isolation was performed and which method was used.

- "Osteogenic differentiation potential" - indicates if capacity to undergo osteogenic differentiation was included in the articles and with which method.

- "Markers found" - indicates gene expression of cell surface markers.

\section{Risk of bias across studies}

The Cochrane collaboration bias summary for potential bias was used to assess the quality of studies and identify papers with intrinsic flaws in method and design [17].

\section{Synthesis of results}

Appropriate data of interest on the previously stated variables were tabulated and discussed.

\section{Statistical analysis}

No meta-analyses could be performed due to the heterogeneity between the studies (different study designs, control groups, and observation periods).

\section{RESULTS \\ Study selection}

Article review and data extraction were performed according to PRISMA flow diagram (Figure 1). The initial electronic and hand search retrieved 4665 citations, 1609 of which were eliminated as not relevant articles. After titles and abstracts were reviewed, 2997 articles were excluded. The inclusion and exclusion criteria were applied to 37 full-text articles. Eleven articles met the predefined criteria and were included in the systematic review.

\section{Exclusion of studies}

The reasons for excluding studies after full-text assessment were as follows: articles [18-29] included data on non-healthy patients suffering from various kinds of cancer, articles $[\underline{30}, \underline{31}, \underline{33}]$ with luck of information about the investigated methods.

\section{Quality assessment}

The quality assessment of the included studies revealed an unknown risk of bias (for one or more key domains) for the majority of included studies $[\underline{4}, \underline{6}, \underline{7}, \underline{9}, \underline{10-12}, \underline{33}, \underline{34}]$, two studies $[\underline{5}, \underline{8}]$ was classified as low risk (of bias for all key domains) (Table 1).

Table 1. Bias summary

\begin{tabular}{|c|c|c|c|c|c|c|c|c|}
\hline Study & $\begin{array}{c}\text { Year of } \\
\text { publication }\end{array}$ & \begin{tabular}{|c|}
$\begin{array}{c}\text { Random } \\
\text { sequence } \\
\text { generation }\end{array}$ \\
\end{tabular} & $\begin{array}{c}\text { Allocation } \\
\text { concealment }\end{array}$ & \begin{tabular}{|c|} 
Blinding of \\
participants \\
and personnel \\
\end{tabular} & \begin{tabular}{|c|} 
Blinding of \\
outcome \\
assessment \\
\end{tabular} & \begin{tabular}{|c|}
$\begin{array}{c}\text { Incomplete } \\
\text { outcome } \\
\text { data }\end{array}$ \\
\end{tabular} & $\begin{array}{c}\text { Selective } \\
\text { reporting }\end{array}$ & \begin{tabular}{|c|}
$\begin{array}{c}\text { Other } \\
\text { sources of } \\
\text { bias }\end{array}$ \\
\end{tabular} \\
\hline Smiler et al. [4] & 2008 & $?$ & $?$ & + & + & + & + & + \\
\hline Castillo-Cardiel et al. [5] & 2016 & $?$ & + & + & + & + & + & + \\
\hline McNulty et al. [6] & 2012 & $?$ & $?$ & + & $?$ & + & + & + \\
\hline Dhar et al. [7] & 2012 & $?$ & $?$ & + & + & + & + & + \\
\hline Marycz et al. [8] & 2016 & + & $?$ & + & + & + & + & + \\
\hline Lyahyai et al. [9] & 2012 & $?$ & $?$ & $?$ & + & + & + & $?$ \\
\hline Kassis et al. [10] & 2006 & $?$ & $?$ & $?$ & + & + & + & $?$ \\
\hline Li et al. [11] & 2015 & $?$ & $?$ & - & $?$ & + & + & + \\
\hline Sato et al. [12] & 2016 & $?$ & $?$ & + & $?$ & + & + & + \\
\hline Motlló et al. [33] & 2014 & $?$ & $?$ & - & + & + & + & + \\
\hline Anguita-Compagnon et al. [34] & 2010 & $?$ & $?$ & + & + & - & + & + \\
\hline
\end{tabular}

$+=$ low risk; $?=$ unclear risk; $-=$ high risk. 


\section{Study characteristics}

In 2008, Smiler et al. [4] performed a research to investigate the presence of MSC needed for bone formation from $\mathrm{PB}$ and $\mathrm{BM}$ aspirate, by means of cell markers, and to ensure where is greater amount of osteogenic stem cells, in BM or in PB?

To answer this questions samples from six patients ranging in age from 23 to 73 were analysed with 6-column flow cytometry using six monoclonal antibody cell markers: CD14, CD34, CD36, CD105, CD106, and CD309 those cell markers relating to bone growth and bone healing. PB and BM aspiration performed at the same time, cells were compared and 50,000 to 100,000 cells were included in each assay for adequate statistical results (Table 2).
The results revealed that $\mathrm{BM}$ contained more osteogenic stem cells than peripheral blood and more osteogenic potential in the $\mathrm{BM}$ than the $\mathrm{PB}$. This brings them to conclude that the ability of multipotent MSCs to form osteoblasts for bone regeneration makes transplanted $\mathrm{BM}$ aspirate a promising tool for enhancing bone regeneration.

Although, Smiler et al. [4] proved that BM contained more osteogenic stem cells than $\mathrm{PB}$, the processes of isolation is invasive. Cells that have similar regenerative function and can be isolated with minimal or no invasive procedure will greatly simplify the bone healing process [11].

Due to the fact that under normal conditions HSPCs are not present in $\mathrm{PB}$ or present in low levels, it is necessary to mobilize HSPCs from BM to PB [13].

Table 2. Characteristics of included studies

\begin{tabular}{|c|c|c|c|c|c|c|c|c|c|}
\hline Study & $\begin{array}{l}\text { Type of } \\
\text { study }\end{array}$ & \begin{tabular}{|c|} 
Model \\
investigated
\end{tabular} & $\begin{array}{c}\text { Patient } \\
\text { no. }\end{array}$ & $\begin{array}{c}\text { Cell } \\
\text { source }\end{array}$ & $\begin{array}{c}\text { Mobilization } \\
\text { procedure } \\
(+\backslash-) \text { and } \\
\text { material }\end{array}$ & $\begin{array}{c}\text { Assay of } \\
\text { mobilization }\end{array}$ & $\begin{array}{c}\text { Apheresis } \\
\text { procedure } \\
(+\backslash-) \\
\text { and method }\end{array}$ & $\begin{array}{c}\text { Osteogenic } \\
\text { differentiation } \\
\text { potential }\end{array}$ & $\begin{array}{l}\text { Markers } \\
\text { found }\end{array}$ \\
\hline $\begin{array}{l}\text { Smiler et al. } \\
\text { [4] }\end{array}$ & $\begin{array}{l}\text { Research } \\
\text { article }\end{array}$ & Humans & 6 & BM PB, & 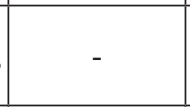 & - & $\begin{array}{l}+, \text { Modern } \\
\text { flow } \\
\text { cytometer }\end{array}$ & - & $\begin{array}{l}\text { CD105+ Using } \\
\text { 6-color flow } \\
\text { cytometry }\end{array}$ \\
\hline $\begin{array}{l}\text { Castillo- } \\
\text { Cardiel et } \\
\text { al. [5] }\end{array}$ & $\begin{array}{l}\text { Randomized } \\
\text { clinical trial }\end{array}$ & Humans & 20 & $\begin{array}{c}\text { Adipose } \\
\text { tissue }\end{array}$ & - & - & r & $\begin{array}{c}+, \text { using } \\
\text { panoramic } \\
\text { radiograph and } \mathrm{CT}\end{array}$ & - \\
\hline $\begin{array}{l}\text { McNulty et } \\
\text { al. [6] }\end{array}$ & Pilot Study & Mice & 97 & PB & $\begin{array}{c}+, \\
\text { AMD3100, } \\
\begin{array}{c}\text { bone marrow } \\
\text { ablation }\end{array}\end{array}$ & $\begin{array}{l}\text { CFU, flow } \\
\text { cytometry, } \\
\text { micro-CT. }\end{array}$ & - & 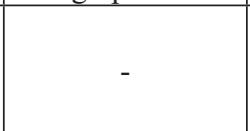 & - \\
\hline $\begin{array}{l}\text { DHAR et } \\
\text { al. [7] }\end{array}$ & Clinical trial & Equine & 10 & \begin{tabular}{|c|} 
PB \\
Adipose \\
tissue
\end{tabular} & $\begin{array}{c}+, \text { hyperbaric } \\
\text { oxygen } \\
\text { therapy }\end{array}$ & $\begin{array}{l}\text { Markers } \\
\text { expression, } \\
\text { cytospin. }\end{array}$ & Ficoll.+ & $\begin{array}{l}+ \text { alizarin red } \\
\text { staining solution }\end{array}$ & $\begin{array}{l}\text { CD51, CD90, } \\
\text { CD105 }\end{array}$ \\
\hline \multirow{2}{*}{$\begin{array}{l}\text { Marycz et } \\
\text { al. [8] }\end{array}$} & \multirow{2}{*}{$\begin{array}{l}\text { Research } \\
\text { article }\end{array}$} & Mice & 90 & \begin{tabular}{|c|}
$\mathrm{BM}$ and \\
$\mathrm{PB}$
\end{tabular} & $\begin{array}{c}+, \text { endurance } \\
\text { exercise }\end{array}$ & $\begin{array}{c}\text { Clonogenic } \\
\text { assay, ELISA }\end{array}$ & - & - & - \\
\hline & & Humans & 12 & $\begin{array}{c}\text { BM and } \\
\text { PB }\end{array}$ & & ELISA & - & - & - \\
\hline $\begin{array}{l}\text { Lyahyai et } \\
\text { al. [9] }\end{array}$ & $\begin{array}{l}\text { Research } \\
\text { article }\end{array}$ & $\begin{array}{l}\text { Sheep- } \\
\text { Ovine }\end{array}$ & 6 & PB & - & - &,$+ \mathrm{NA}$ & $\begin{array}{c}+ \text { alizarin red } \\
\text { staining solution } \\
\text { (cytochemical) }\end{array}$ & $\begin{array}{c}\text { CD105, CD73, } \\
\text { CD90 }\end{array}$ \\
\hline $\begin{array}{l}\text { Kassis et al. } \\
{[10]}\end{array}$ & $\begin{array}{l}\text { Original } \\
\text { article }\end{array}$ & Human & NA & PB &,$+ \mathrm{G}-\mathrm{CSF}$ & NA & $\begin{array}{c}+, \text { COBE } \\
\text { Spectra } \\
\text { apheresis } \\
\text { system + } \\
\text { isolation by } \\
\text { FMB. }\end{array}$ & \begin{tabular}{|c|} 
+ nitro-blue \\
tetrazolium/ \\
indolylp-hosphate \\
staining to \\
observe alkaline \\
phosphatase \\
activity of the \\
osteogenic cells
\end{tabular} & $\begin{array}{l}\text { CD45, CD105, } \\
\text { CD90, } \\
\text { vimentin, } \\
\text { fibronectin. }\end{array}$ \\
\hline Li et al. [11] & $\begin{array}{l}\text { Original } \\
\text { research }\end{array}$ & Mice & NA & PB & - & - & - & $\begin{array}{l}+ \text { alizarin red } \\
\text { staining solution }\end{array}$ & $\begin{array}{l}\text { CD45-(BD- } \\
\text { MSC) using } \\
\text { coculture } \\
\text { system from } \\
\text { PB }\end{array}$ \\
\hline $\begin{array}{l}\text { Sato et al. } \\
{[12]}\end{array}$ & $\begin{array}{l}\text { Research } \\
\text { article }\end{array}$ & Feline & 22 & PB & - & - & + & $\begin{array}{c}+ \text { alizarin red } \\
\text { staining solution } \\
\text { (cytochemical) }\end{array}$ & CD44, CD90 \\
\hline $\begin{array}{l}\text { Motlló et al. } \\
\text { [33] }\end{array}$ & $\begin{array}{l}\text { Research } \\
\text { article }\end{array}$ & Human & 133 & PB &,$+ \mathrm{G}-\mathrm{CSF}$ & $\begin{array}{l}\text { EPICS XL- } \\
\text { MCL flow } \\
\text { cytometer. }\end{array}$ & $\begin{array}{c}+, \text { COBE } \\
\text { Spectra } \\
\text { apheresis } \\
\text { system }\end{array}$ & 20 & - \\
\hline $\begin{array}{l}\text { Anguita- } \\
\text { Compagnon } \\
\text { et al. [34] }\end{array}$ & $\begin{array}{c}\text { Retrospective } \\
\text { study }\end{array}$ & Humans & $\begin{array}{c}31 \\
\text { donors }\end{array}$ & PB &,$+ \mathrm{G}-\mathrm{CSF}$ & \begin{tabular}{|c|}
$\begin{array}{c}\text { Flow cytometry, } \\
\text { clonogenic } \\
\text { assay. }\end{array}$ \\
\end{tabular} & $\begin{array}{l}+ \text { COBE } \\
\text { Spectra cell } \\
\text { processor }\end{array}$ & - & - \\
\hline
\end{tabular}

$\mathrm{NA}=$ not applicable; $\mathrm{PB}=$ peripheral blood $\mathrm{BM}=$ bone marrow $; \mathrm{CT}=$ computed tomography. 
Studies, reviewed in this paper presented mobilization procedure on different animals and with different material being used. In 2010, Anguita-Compagnon et al. [34] perform retrospective study on healthy 28 human donors (20 adult, 8 children) for PBSC allotransplantation using G-CSF (filgrastim) $5 \mu \mathrm{g} / \mathrm{kg}$ twice a day until end of collection. Adults undergo 23 mobilization procedures and 56 apheresis, while children went through 8 mobilization and 23 apheresis which started within $2-4 \mathrm{~h}$ after administration of G-CSF and PB CD34+ cell count started from day 4. The study showed higher yields with children than adults, good correlation between $\mathrm{CD} 34+$ cells and CFU-GM among PBSC harvests, for same given level of PB CD34+ cells healthy donors and patients obtain similar yield per BV.

Age is well known factor influencing mobilization results, because the fact that bone marrow reserve decrease with age. However in 2014, Motlló et al. [33] attempted to explore this influence on healthy donor on hematopoietic stem cells transplantation (HSCT), the 133 healthy human donor who undergo mobilization and apheresis were divided into 2 groups; 89 young donors $(<55$ years old $)$ and 44 old donor group ( $>55$ years old). The material used was G-CSF (filgrastim) $5 \mu \mathrm{g} / \mathrm{kg}$ that was administrated twice daily for 5 days and then PB CD34+ cell count started. The main conclusion of this study was that donor age has no influence on quality of mobilization and apheresis procedures and no difference observed in the main outcome of HCST.

The current state of the art in using stem cells in tissue repair is that they are harvested, manipulated and then implanted locally at the site of injury []. However, repopulation of tissues may be triggered by injury or a hypoxic environment, recruiting circulating-stem cell participation in wound-healing regenerative activity [4]. On 2012, McNulty et al. [6] performed a pilot study with 3 experiences, first experiment aim was to prove that AMD3100 mobilize mice adult stem cells; performed by Single injection for 7 mice of $5 \mathrm{mg} /$ $\mathrm{kg}$ AMD3100 plerixafor was administrated and for 8 mice injection of $5 \mathrm{mg} / \mathrm{kg}$ saline after the injection they were evaluated. It was found that AMD3100 increased CFUs indicative of MSCs, HSCs, and EPCs in the PB.

In the second experiment McNulty et al. [] tests whether stem cells can be mobilized to the PB after the marrow ablation procedure only without the use of mobilization material. They use 25 female mice who underwent marrow ablation surgery in the distal left femur and they were sacrificed $4,7,10,14$, or 21 days postoperatively and PB was collected for flow cytometry analysis. The results showed distinct populations of MSCs; HSCs, EPCs were identified within the $\mathrm{PB}$ and this suggests that ablation surgery alone mobilizes MSCs, HSCs, and EPCs to the PB. This brought them to their third experiment which evaluates whether AMD3100 increases or prolongs the natural mobilization in response to injury (ablation surgery) and if this enhances bone regeneration in the model. Authors used 57 female mice that underwent femoral bone marrow ablation surgery in the left femur. Some of the mice received a single injection of AMD3100 (5 mg/kg) and others received saline (baseline controls) and were sacrificed after 7, 14, or 21 days. The bone regeneration was assayed by micro-CT (computed tomography). At the $21^{\text {st }}$ day the mice treated with AMD3100 had higher $(\mathrm{P}=0.047)$ $\mathrm{BV} / \mathrm{TV}$ than those treated with saline. Compared to baseline controls, the surgery groups had increased $\mathrm{BV} / \mathrm{TV}$ in all three regions of interest whether saline or AMD3100 was administered. The conclusion of this study is that the use of the CXCR4 antagonist, AMD3100, has an effect on bone formation in at least three microenvironments: ectopic, cranial, and appendicular in mice. Furthermore it was found that skeletal injury itself induces mobilization of stem cells and that administration of AMD3100 intensifies the mobilization of stem cells [ $[6]$.

Another method for mobilization is hyperbaric oxygen treatment that has been reported to mobilize hematopoietic stem cell and release of endothelial progenitor cells in to the $\mathrm{PB}$ in humans and mice, but similar experiments have not been done in horses and the exact mechanism is still unknown. Hyperbaric oxygen is used as a treatment therapy for a variety of disorders in human and animals [7].

Dhar et al. [7] perform an experiment to assess the effect of hyperbaric oxygen therapy on the circulating concentrations of peripheral blood MSCs. Six horses participated in the study: 3 of them yield PB MSCs before and 3 did not. Vertical hyperbaric chamber at $2.52 \times 107 \mathrm{~Pa}$, for $60 \mathrm{~min}, 3$ days with mean inspired oxygen concentration was $1553 \mathrm{mmHg}$ during therapy. The results show a 2-8-fold increase in CD90-positive cells.

In the mononuclear fraction, this grew and proliferated into MSCs in all 6 mares after treatment. The 3 mares that did not yield any MSCs before therapy did not yield MSCs after hyperbaric oxygen treatment. Similar percentages of lymphocytes and monocytes were obtained before and after hyperbaric oxygen therapy in the MNCs, suggesting that this was not an artefact due to the isolation procedure. This brought them to conclude that; the hyperbaric oxygen therapy has positive effect on CD90-positive cells that significant increased and mobilization of endothelial 
progenitor cells from $\mathrm{BM}$ into the $\mathrm{PB}$ can increase via an elevation in nitric oxide production.

Another method for mobilization was suggested in 2016 by Marycz et al. [ 8 ] after some evidences reported an HSPCs and EPCs expansion can occur in $\mathrm{BM}$ in response to endurance exercise, he performed a research article to test if the BMresiding VSELs would respond in a similar way as HSPCs to endurance exercise after a short, intensive run on rotating wheels or after repeated daily running exercise on a treadmill. Furthermore, mobilization of VSELs and HSPCs in healthy young athletes was evaluated after a $10 \mathrm{~km}$ run. In the research they tested 12 humans and 90 mice. Mice were trained daily for 1 hour on a treadmill some for periods of 5 days and some for 5 weeks. Human were trained in long-distance running for one year, six times per week. Analysis of the results was FACS-based analyses and RT-PCR of murine and human VSELs and HSPCs from collected PB and BM. The result demonstrated that physical activity mobilizes HSPCs, both in mice and humans and may have positive effects on the expansion of early stem cells. This may explain the importance of regular exercise on tissue and organ rejuvenation and the improvement of life quality.

A simple process based on plastic adherence reduced all unwanted cellular subsets from mobilized samples due to the fact that hematopoietic progenitors, monocytes and neutrophils enriched in peripheral blood in response to G-CSF treatment, have the ability to adhere to plastic surfaces [35].

The need for high number of potent MSC sets the basis need for new methods of isolation for tissue regeneration and cell therapy. Based on these observations, cultures based on fibrin matrices were proposed for cell culture and for cellular tissue repair therapy. Fibrinogen provides an interim matrix that supports cell adhesion, proliferation and migration involved in wound repair. Back in 2006, Kassis et al. [10] performed original article on humans based on preliminary study that have showed FMB (fibrin microbeads) are able to separate MSC from a population of rat $\mathrm{BM}$ at a higher yield than the conventional isolation method [ $\underline{36}]$.

Kassis et al. [10] evaluated the ability of FMB to isolate MSC from G-CSF of mobilized blood of healthy donors collected by apheresis, and to prove the cells pluripotency by their ability to differentiate into various mesodermal lineage. The results showed that out of 11 samples of mobilized blood 8 were isolated with a significant number of MSC, which could be further expanded. This yield downloaded and expanded on the flasks at days $17-18$ by the FMB technique.
The isolated MSC were able to expand and differentiate into bone-forming cells and to be injected into a target organ while still attached to the FMB. This may permit simpler delivery of the cells in conditions that allow for better survival and better chances to regenerate the defected tissue. This suggests that FMB are able to isolate high numbers of MSC from the mobilized PBPC of adult healthy individuals, with low contamination by other cell types.

During the last decade there has been an important effort within the scientific community to focus on the characterization of MSC obtained from different species [9]. For example in 2012, Lyahyai et al. [9] performed a study to investigate the possibility of MSC isolation from ovine peripheral blood (oPBMSCs) and their characterization in vitro properties. After plastic adherent fibroblast like cells were obtained from $25 \mathrm{ml}$ of $\mathrm{PB}$ of 6 sheeps, they were analysed for their proliferative, gene expression and differentiation potential. The results revealed that; the markers which were positive to the isolated cells were CD29, CD73 CD90 and weak signal for CD105 also emerged, while CD45 and CD134 where not expressed.

When Lyahyai et al. [9] tested the osteogenic mineralization potential, transcript expression of the osteogenic markers COL1A1 and BGLAP was evaluated too by RT-qPCR at days 7, 14 and 21 of culture. Calcium deposits were confirmed with alizarin red staining only in day 21 . The induction period reported for oBM-MSC mineralisation ranges from 21 - 35 days and the explanation for the weak staining observed could be due to the short period of induction. Moreover, although they assume that COL1A1 considers an early marker of osteoprogenitor cells, oBMMSCs express increased or declined levels of COL1A1, what suggests that COL1A1 may not be suitable for monitoring osteogenesis in oPB-MSCs. In contrast, BGLAP was upregulated during the differentiation process and expressed on $21^{\text {st }}$ day.

Later in 2016, Sato et al. [12] performed a similar article in order to establish a procedure for isolation of MSCs from feline PB, to demonstrate their capacity to differentiate and to find the markers of fPB-MSCs, by taking $12 \mathrm{~mL}$ of PB from 22 domestic cats.

Several culture conditions were used to evaluate the influence of culture medium on feline PBMCs. It was found that medium containing both FBS and AP resulted in enhanced adherence and propagation of fPB-MSCs. While number of PBMCs culture medium containing only FBS diminished over time, as well as culture medium supplemented with recombinant feline GM-CSF and fBM-MSCsCM. 
In culture medium containing only AP, the cells increased in size and became multinucleated, however these cells presented no spindle shaped fPB-MSCs and became confluent after 21 days. These results suggest that different methods used to isolate PBMSCs between animal species. In order to find the positive markers for fPB-MSCs they used flow cytometry which expressed the mesenchymal markers CD44 and CD90, and didn't expressed CD4 and MHC II, here they found similarity to MSCs derived from other feline tissues and PB-MSCs from other mammals. To assess osteogenic differentiation in vitro, fPB-MSCs were seeded in a 12-well plate and cultured under osteogenic conditions. Osteogenic differentiation was confirmed by positive alizarin red staining of extracellular calcium matrix.

As it was mentioned before, MSCs have the capacity to differentiate into osteogenic cells and can be used as an alternative for conventional graft treatments been demonstrated before in large bone defects in animal models.

In 2016, Castillo-Cardiel et al. [5] performed randomized clinical trial on 20 humans to evaluate regeneration time and to increase bone quality by testing effectiveness of AMSCs from adipose tissue application in mandibular angle fractures. Patients were divided into 2 groups while only 1 group the Study Group passes reduction with application of AMSCs, and the Control Group passed only simple fracture reduction. Intensity and density were evaluated in normal bone and fractured bone at 4 and 12 weeks after surgery using panoramic radiography and CT. The result showed that similar ossification values were obtained after 4 weeks when the use of AMSCs was compared to simple fracture reduction. However, after 12 weeks, the study group had a $36.48 \%$ higher rate of ossification. Patients presented less pain and reaching an earlier return of the patients to their daily activities.

The present results support the effectiveness of AMSCs in the treatment of mandibular angle fractures and better bone regeneration.

In 2015, an original article performed by Li et al. [11] after they have been exposed to undefined MSC-like population that show improved healing in rabbit ulna. They investigate cell-based therapy to enhance long bone healing of calvarial bone defects through intramembranous ossification by isolating the cells responsible for the healing process derived from PB. Authors discovered a population of non-hematopoietic cells that although derived from mouse peripheral blood, fulfil ISCT criteria defined for human MSCs, and named these cells "blood derived mesenchymal stem cells" (BD-MSCs).
The experiment was done on mice after creation of $4 \mathrm{~mm}$ (critical size) calvarial defects on the right parietal bone, the pop1 cell-seeded HAPLGA scaffolds or control unseeded HA-PLGA scaffolds were placed into the defect and closed with interrupted 7-0 Vicryl suture. Quantitative bone analysis was performed immediately after surgery and at weeks $2,4,6$, and 8 by micro CT. The result showed that defects treated with pop1 cell-seeded scaffolds healed at a faster rate than the control scaffolds. At $8^{\text {th }}$ week, healing in pop1 cell-seeded scaffolds was $69.65 \%$ versus $14.94 \%$ of the unseeded control scaffolds.

Their results led them to conclude that treatment with pop1 cells significantly increased osteogenesis and bone regeneration in critical-sized calvarial defects and even though BD-MSCs differ from the circulating stem cells by not express CD105 which is a critical surface marker for MSC determination. BD-MSCs provide new evidence that MSCs can be found and be isolated from $\mathrm{PB}$ and an ideal cell type for the development of cell-based therapy to enhance bone repair owing to its high cell calcification activity in response to osteogenic differentiation. Furthermore, they discovered that among pop1 cells the group who was responsible for healing of the critical-sized calvarial defects is a group of CD45- fibroblastic cells who's responsible for the calcification activity of pop1 cells.

\section{DISCUSSION}

The application of autogenous bone graft is interfered by multiple risks as infection, rejection, donor site morbidity, high cost and further complications due to additional surgical procedures for harvesting the graft, and an alternative approach as AMSCs transplantation is proposed to fulfil the need for repair of large bone skeletal defects [1-3]. Over the last decades, scientists have discovered a wide array of stem cells from a range of tissues, but the presence of HSPC's in PB was first detected in patients undergoing chemotherapy after observing increase in circulating CD34+ cells in 1971 [6,ㅣㄹ] Smiler et al. [4], in their study, investigate where exist greater amount of osteogenic stem cells needed for bone formation under normal conditions, in $\mathrm{PB}$ or $\mathrm{BM}$ and the results revealed that $\mathrm{BM}$ contained more osteogenic stem cells than $\mathrm{PB}$ and hence more osteogenic potential exist in BM. Even though BM represents the most well documented source of cells for tissue regeneration, the processes of isolation is invasive, traumatic, and the amount of material extracted is limited and requires anaesthesia $[\underline{10}, \underline{12}]$. 
Due to the fact that under normal conditions HSPCs are not present in $\mathrm{PB}$ or present in low levels, it is necessary to mobilize HSPCs from BM to PB [13]. Mobilization is achieved by the administration of cytokines such as G-CSF, or plerixafor, other derivatives were also mentioned in the literature [14]. Several factors have been reported to affect mobilization as: age, sex, bone marrow involvement, steady state PB counts, and premobilization platelet count. While male sex, higher body mass index, higher agent dosage, and higher premobilization white blood cells (WBCs) associated with a better efficiency [34]. Age is well known factor influencing mobilization results, due to the fact that bone marrow reserve decrease with age, this statement was proved by Anguita-Compagnon et al. [34] which present higher yields with children than adults in their study, However Motlló et al. [33] attempted to explore this influence on healthy adult donor and found that donor age has no influence on quality of mobilization and apheresis procedures and no difference observed in the main outcome of HCST.

The leading reason for an alternative ways to mobilize MSC is materials impact on the human body e.g. G-CSF induces headache, fatigue, muscle and bone pain which also can be induced due high dosage of G-CSF, females also experience headache, nausea and fever. Moreover G-CSF induces sometimes high WBCs levels, which could generate vascular complications. Splenic rupture, allergic reaction and two cases of arterial thrombosis have been reported in literature as rare complications in healthy donors. Plerixafor can induce transient side effects as gastro intestinal discomfort, diarrhea, nausea, erythema in injection site, headache and paraesthesia $[\underline{13}, \underline{37}]$.

Hyperbaric oxygen is used as a treatment therapy for a variety of disorders in human and animals [7], and Dhar et al. [7] suggested to assess the effect of hyperbaric oxygen therapy on the circulating concentrations of peripheral blood MSCs of horses, the results show an increase in CD90+ cells due to elevation in nitric oxide production, this led to mobilization of endothelial progenitor cells from $\mathrm{BM}$ into the PB. This states that hyperbaric oxygen therapy has positive effect on mobilization of MSC.

Another method for mobilization was demonstrated by Marycz et al. [ $\underline{8}$ ] who proved that physical activity mobilizes HSPCs, both in mice and humans and may have positive effects on the expansion of early stem cells.

Experimental evidence of large and small bone defects repair have been proven due to the ability of BMSCs application when implanted within hydroxyapatite- based scaffolds. Furthermore, it was demonstrated that human processed lipoaspirate cells, isolated from adipose tissue, could be induced to differentiate into mesenchyme tissue through incubation in specific media and suggesting the applicability of adipose tissue-derived stromal cells (ADSCs) to bone repair, animal studies not only revealed the far greater accessibility of ADSCs, but also the greater number of progenitors in lipoaspirates (100 times more than BMSC for same given volume) [1]. Subsequently, Castillo-Cardiel et al. [5] tried to evaluate bone regeneration time and to increase bone quality by testing effectiveness of AMSCs application in human mandibular angle fractures. The result showed that the group who was treated with ADSCs had a $36.48 \%$ higher rate of ossification in compare to the group who underwent reduction procedure only. The present results support the effectiveness of AMSCs in the treatment of mandibular angle fractures and better bone regeneration. But still, the harvesting process of ADSCs is invasive, traumatic and requires anaesthesia.

An emerging concept is to employ endogenous stem cells mobilized to the PB to achieve the same end point and since collection of blood samples is minimal invasive procedure, cells with similar potential from PB may be a source of progenitor cells in clinical situations and will greatly simplify the bone healing process.

During the last decade important effort within the scientific community to focus on the characterization of MSC obtained from PB of different species was noticed [9]. Lyahyai et al. [9] and Sato et al. [12] performed an similar articles investigated the possibility of MSC isolation from animal peripheral blood (oPB-MSCs) and their characterization in vitro properties, in both researches osteogenic differentiation was confirmed by positive alizarin red staining of extracellular calcium matrix and meet all the requirements of ISCT.

Nowadays, tissue repair with stem cells is experimental. Stem cells are harvested by apheresis, manipulated and then implanted locally at the site of injury [9], only McNulty et al. [6] thought differently and tests whether mice stem cells can be mobilized to $\mathrm{PB}$ after marrow ablation procedure only without the use of mobilization material. The results showed distinct populations of MSCs within the PB this means that ablation surgery alone mobilizes MSCs, HSCs, and EPCs to the PB. Additionally they proved that skeletal injury alone induces mobilization of stem cells, and administration of AMD3100 (plerixafor) intensifies the mobilization of stem cells. 


\section{CONCLUSIONS}

Ensuring safety is an important mean for allogeneic donors of peripheral blood hematopoietic stem/ progenitor cells and this is why the first question addressed was what kind of side effects can occur after administration of mobilization material to a healthy person. The immediate side effects after mobilization by granulocyte-colony-stimulating factor can induce headache, fever, nausea, muscle and bone pain which also can be induced due high dosage of the material. Moreover granulocyte-colony-stimulating factor induces sometimes high white blood cells level, which could generate vascular complications. Plerixafor can induce transient side effects as gastro intestinal discomfort, diarrhea, nausea, erythema in injection site, headache and paraesthesia. However, long-term medical follow-ups were not mentioned in the current literature and it suggests that further investigation should be conducted in order to confirm the safety of granulocyte-colony-stimulating factor and plerixafor in donors. Due to the questionable impact of mobilization materials on the human body, an alternative ways to mobilize mesenchymal stem cells were suggested as hyperbaric oxygen and physical activity, owing to their prohematopoietic effect, a positive effect on circulating concentrations of peripheral blood mesenchymal stem cells.

After understanding that mesenchymal stem cells can be mobilized from bone marrow into peripheral blood, it was interesting to see if mesenchymal stem cells isolated from peripheral blood have the same characteristic feature as purposed by the International Society for Cellular Therapy. Studies reviewed in this paper presented mobilization procedure on different models, this allow us to answer on our second question and to conclude that plastic adherence, mesenchymal markers and mesenchymal differentiation were expressed in all examined models and the peripheral blood isolated cells fulfil the mesenchymal stem cells criteria, as defined by International Society for Cellular Therapy.

Due to the fact that bone marrow reserve decrease with age, our last question was to evaluate whether age can influence mobilization outcomes. Several authors presented higher yields with children than adults in their studies, conversely other authors found that donor age has no influence on quality of mobilization and apheresis procedures. This led us to conclude that in order to achieve better results perhaps further research must be conducted investigating the effect of age on mobilized mesenchymal stem cells.

Currently, insufficiency of data display in the literature on potential therapeutic applications of peripheral blood stem cells therapy for bone tissue regeneration, suggests that bone tissue engineering is a potential alternative strategy in bone regeneration and bone defect repair that fill the clinical need for autologous bone transplantation.

Furthermore, mobilization and collection of peripheral blood stem cells can be significantly improved with close monitoring the patient's mobilization progress, numbers of hematopoietic stem/progenitor cells, and the use of both conventional and newer mobilization agents.

\section{ACKNOWLEDGMENTS AND DISCLOSURE STATEMENTS}

The authors confirm that this article content has no conflict of interest with any financial organization regarding the material discussed in the article.

\section{REFERENCES}

1. Fisher JN, Peretti GM, Scotti C. Stem Cells for Bone Regeneration: From Cell-Based Therapies to Decellularised Engineered ExtracellularMatrices. Stem Cells Int. 2016;2016:9352598. [Medline: 26997959] [PMC free article: 4779529] [doi: $10.1155 / 2016 / 9352598]$

2. Walmsley GG, Ransom RC, Zielins ER, Leavitt T, Flacco JS, Hu MS, Lee AS, Longaker MT, Wan DC. Stem Cells in Bone Regeneration. Stem Cell Rev. 2016 Oct;12(5):524-529. [Medline: 27250635] [doi: 10.1007/s12015-016-9665-5]

3. Zhang J, Guan J, Qi X, Ding H, Yuan H, Xie Z, Chen C, Li X, Zhang C, Huang Y. Dimethyloxaloylglycine Promotes the Angiogenic Activity of Mesenchymal Stem Cells Derived from iPSCs via Activation of the PI3K/Akt Pathway for Bone Regeneration. Int J Biol Sci. 2016 Apr 8;12(6):639-52. [Medline: 27194942] [PMC free article: 4870708] [doi: $10.7150 /$ ijbs.14025]

4. Smiler D, Soltan M, Albitar M. Toward the identification of mesenchymal stem cells in bone marrow and peripheral blood for bone regeneration. Implant Dent. 2008 Sep;17(3):236-47. [Medline: 18784524] [doi: 10.1097/ID.0b013e3181835b13]

5. Castillo-Cardiel G, López-Echaury AC, Saucedo-Ortiz JA, Fuentes-Orozco C, Michel-Espinoza LR, Irusteta-Jiménez L, Salazar-Parra M, González-Ojeda A. Bone regeneration in mandibular fractures after the application of autologous mesenchymal stem cells, a randomized clinical trial. Dent Traumatol. 2017 Feb;33(1):38-44. [Medline: 27513920] [doi: $10.1111 /$ edt.12303] 
6. McNulty MA, Virdi AS, Christopherson KW, Sena K, Frank RR, Sumner DR. Adult stem cell mobilization enhances intramembranous bone regeneration: a pilot study. Clin Orthop Relat Res. 2012 Sep;470(9):2503-12. [Medline: 22528386] [PMC free article: 3830081] [doi: 10.1007/s11999-012-2357-9]

7. Dhar M, Neilsen N, Beatty K, Eaker S, Adair H, Geiser D. Equine peripheral blood-derived mesenchymal stem cells: isolation, identification, trilineage differentiation and effect of hyperbaric oxygen treatment. Equine Vet $\mathrm{J}$. 2012 Sep;44(5):600-5. [Medline: 22333000] [doi: 10.1111/j.2042-3306.2011.00536.x]

8. Marycz K, Mierzejewska K, Śmieszek A, Suszynska E, Malicka I, Kucia M, Ratajczak MZ. Endurance Exercise Mobilizes Developmentally Early Stem Cells into Peripheral Blood and Increases Their Number in Bone Marrow: Implications for Tissue Regeneration. Stem Cells Int. 2016;2016:5756901. [Medline: 26664409] [PMC free article: 4655293] [doi: $10.1155 / 2016 / 5756901]$

9. Lyahyai J, Mediano DR, Ranera B, Sanz A, Remacha AR, Bolea R, Zaragoza P, Rodellar C, Martín-Burriel I. Isolation and characterization of ovine mesenchymal stem cells derived from peripheral blood. BMC Vet Res. 2012 Sep 22;8:169. [Medline: 22999337] [PMC free article: 3514285] [doi: 10.1186/1746-6148-8-169]

10. Kassis I, Zangi L, Rivkin R, Levdansky L, Samuel S, Marx G, Gorodetsky R. Isolation of mesenchymal stem cells from G-CSF-mobilized human peripheral blood using fibrinmicrobeads. Bone Marrow Transplant. 2006 May;37(10):967-76. [Medline: 16670702] [doi: 10.1038/sj.bmt.1705358]

11. Li S, Huang KJ, Wu JC, Hu MS, Sanyal M, Hu M, Longaker MT, Lorenz HP. Peripheral blood-derived mesenchymal stem cells: candidate cells responsible for healing critical-sized calvarial bone defects. Stem Cells Transl Med. 2015 Apr;4(4):359-68. [Medline: 25742693] [PMC free article: 4367504] [doi: 10.5966/sctm.2014-0150]

12. Sato K, Yamawaki-Ogata A, Kanemoto I, Usui A, Narita Y. Isolation and characterisation of peripheral blood-derived feline mesenchymal stem cells. Vet J. 2016 Oct;216:183-8. [Medline: 27687950] [doi: 10.1016/j.tvj1.2016.08.009]

13. Hequet $\mathrm{O}$. Hematopoietic stem and progenitor cell harvesting: clinical advanced and clinical utility. J Blood Med. 2015 Feb 18;6:55-67. [Medline: 25733943] [PMC free article: 4340371] [doi: 10.2147/JBM.S52783]

14. Yuan S, Wang S. How do we mobilize and collect autologous peripheral blood stem cells? Transfusion. 2017 Jan;57(1): 13-23. [Medline: 27731496] [doi: 10.1111/trf.13868]

15. Chien PF, Khan KS, Siassakos D. Registration of systematic reviews: PROSPERO. BJOG. 2012 Jul;119(8):903-5. [Medline: 22703418] [doi: 10.1111/j.1471-0528.2011.03242.x]

16. Moher D, Liberati A, Tetzlaff J, Altman DG, The PRISMA Group. Preferred Reporting Items for Systematic Reviews and Meta-Analyses: The PRISMA Statement. J Clin Epidemiol 2009: 62:1006-1012. [Medline: 19631508] [doi: 10.1016/j.jclinepi.2009.06.005]

17. Higgins JPT, Green S. Cochrane Handbook for Systematic Reviews of Interventions version 5.1.0. The Cochrane Collaboration, 2011. [URL: http://training.cochrane.org/handbook]

18. Nademanee AP, DiPersio JF, Maziarz RT, Stadtmauer EA, Micallef IN, Stiff PJ, Hsu FJ, Bridger G, Bolwell BJ. Plerixafor plus granulocyte colony-stimulating factor versus placebo plus granulocyte colony-stimulating factor for mobilization of CD34(+) hematopoietic stem cells in patients with multiple myeloma and low peripheral blood CD34(+) cell count: results of a subset analysis of a randomized trial. Biol Blood Marrow Transplant. 2012 Oct;18(10):1564-72. [Medline: 22683613] [doi: 10.1016/i.bbmt.2012.05.017]

19. Yuan S, Nademanee A, Forman SJ, Wang S. Use of plerixafor in patients with Hodgkin lymphoma with poor mobilization of peripheral blood stem cells. Leuk Lymphoma. 2013 Mar;54(3):646-8. [Medline: 22812457] [doi: 10.3109/10428194.2012.713480]

20. Maziarz RT, Nademanee AP, Micallef IN, Stiff PJ, Calandra G, Angell J, Dipersio JF, Bolwell BJ. Plerixafor plus granulocyte colony-stimulating factor improves the mobilization of hematopoietic stem cells in patients with non-Hodgkin lymphoma and low circulating peripheral blood CD34+ cells. Biol Blood Marrow Transplant. 2013 Apr;19(4):670-5. [Medline: 23333777] [doi: 10.1016/j.bbmt.2013.01.005]

21. Takahashi H, Kato M, Kikuchi A, Hanada R, Koh K. Delayed short-term administration of granulocyte colony-stimulating factor is a good mobilization strategy for harvesting autologous peripheral blood stem cells in pediatric patients with solid tumors. Pediatr Transplant. 2013 Nov;17(7):688-93. [Medline: 23962050] [doi: 10.1111/petr.12137]

22. Moon JH, Kim MJ, Song SY, Lee YJ, Choi YY, Kim SH, Lee YH. Safety and efficacy of G-CSF mobilization and collection of autologous peripheral blood stem cells in children with cerebral palsy. Transfus Apher Sci. 2013 Dec;49(3):516-21. [Medline: 24035522] [doi: 10.1016/j.transci.2013.08.003]

23. Schmitt M, Publicover A, Orchard KH, Görlach M, Wang L, Schmitt A, Mani J, Tsirigotis P, Kuriakose R, Nagler A. Biosimilar G-CSF based mobilization of peripheral blood hematopoietic stem cells for autologous and allogeneic stem cell transplantation. Theranostics. 2014 Jan 23;4(3):280-9. [Medline: 24505236] [PMC free article: 3915091] [doi: $10.7150 /$ thno.7752]

24. Cesaro S, Tridello G, Prete A, Dallorso S, Cannata E, Massaccesi E, Risso M, De Bortoli M, Caselli D. Biosimilar granulocyte-colony-stimulating factor for mobilization of autologous peripheral blood stem cells in pediatric hematologyoncology patients. Transfusion. 2015 Feb;55(2):246-52. [Medline: 25070657] [doi: 10.1111/trf.12789]

25. Gac AC, Azar N, Daguindau E, Cartron G, Fornecker LM, Gyan E, Broussais-Guillaumot F, Garidi R, Choufi B, Chantepie SP, Béné MC, Guiéze R, Bijou F, Gressin R, Amorim S, Damaj G. Does bendamustine impact the mobilization of peripheral blood stem cells? A multicenter retrospective study of 23 cases. Leuk Lymphoma. 2016 May;57(5):1149-53. [Medline: 26879408] [doi: 10.3109/10428194.2016.1140160] 
26. Galli M, Lessi F, Rambaldi A, Fedrigo M, Rosa GD, Adami F. Mobilization of peripheral blood hematopoietic stem cells by granulocyte-colony stimulating factor and plerixafor in patients with cardiac AL amyloidosis. Amyloid. 2015;22(4): 259-60. [Medline: 26587896] [doi: 10.3109/13506129.2015.1104295]

27. Schmitt M, Hoffmann JM, Lorenz K, Publicover A, Schmitt A, Nagler A. Mobilization of autologous and allogeneic peripheral blood stem cells for transplantation in haematological malignancies using biosimilar G-CSF. Vox Sang. 2016 Aug;111(2):178-86. [Medline: 27509033] [doi: 10.1111/vox.12397]

28. Teusink A, Pinkard S, Davies S, Mueller M, Jodele S. Plerixafor is safe and efficacious for mobilization of peripheral blood stem cells in pediatric patients. Transfusion. 2016 Jun;56(6):1402-5. [Medline: 27079854] [doi: 10.1111/trf.13599]

29. Milone G, Martino M, Spadaro A, Leotta S, Di Marco A, Scalzulli P, Cupri A, Di Martina V, Schinocca E, Spina E, Tripepi G. Plerixafor on-demand combined with chemotherapy and granulocyte colony-stimulating factor: significant improvement in peripheral blood stem cells mobilization and harvest with no increase in costs. Br J Haematol. 2014 Jan;164(1):113-23. [Medline: 24138497] [doi: 10.1111/bjh.12606]

30. Tae Young A, Kang JH, Kang DJ, Venkatesan J, Chang HK, Bhatnagar I, Chang KY, Hwang JH, Salameh Z, Kim SK, Kim HT, Kim DG. Interaction of stem cells with nano hydroxyapatite-fucoidan bionanocomposites for bone tissue regeneration. Int J Biol Macromol. 2016 Dec;93(Pt B):1488-1491. [Medline: 27402459] [doi: 10.1016/j.ijbiomac.2016.07.027]

31. Vural AC, Odabas S, Korkusuz P, Yar Sağlam AS, Bilgiç E, Çavuşoğlu T, Piskin E, Vargel İ. Cranial bone regeneration via BMP-2 encoding mesenchymal stem cells. Artif Cells Nanomed Biotechnol. 2017 May;45(3):544-50. [Medline: 27002739] [doi: 10.3109/21691401.2016.1160918]

32. Soltan M, Rohrer MD, Prasad HS. Monocytes: super cells for bone regeneration. Implant Dent. 2012 Feb;21(1):13-20. [Medline: 22214990] [doi: 10.1097/ID.0b013e31823fcf85]

33. Motlló C, Sancho JM, Grífols JR, Juncà J, Morgades M, Ester A, Rodríguez I, Vives S, Batlle M, Guardia R, Ferrà C, Gallardo D, Millá F, Feliu E, Ribera JM. Mobilization and engraftment of peripheral blood stem cells in healthy related donors >55 years old. Cytotherapy. 2014 Mar;16(3):406-11. [Medline: 24176544] [doi: 10.1016/j.jcyt.2013.08.005]

34. Anguita-Compagnon AT, Dibarrart MT, Palma J, Paredes L, Mosso C, Montalva R, Salas L, Araos D, Delgado I, Majlis A. Mobilization and collection of peripheral blood stem cells: guidelines for blood volume to process, based on CD34positive blood cell count in adults and children. Transplant Proc. 2010 Jan-Feb;42(1):339-44. [Medline: 20172346] [doi: 10.1016/i.transproceed.2009.11.003]

35. Beloki L, Ciaurriz M, Mansilla C, Zabalza A, Perez-Valderrama E, Samuel ER, Lowdell MW, Ramirez N, Olavarria E. CMV-specific $\mathrm{T}$ cell isolation from G-CSF mobilized peripheral blood: depletion of myeloid progenitors eliminates non-specific binding of MHC-multimers. J Transl Med. 2014 Nov 19;12:317. [Medline: 25406933] [PMC free article: 4243324] [doi: 10.1186/s12967-014-0317-8]

36. Gurevich O, Vexler A, Marx G, Prigozhina T, Levdansky L, Slavin S, Shimeliovich I, Gorodetsky R. CMV-specific $\mathrm{T}$ cell isolation from G-CSF mobilized peripheral blood: depletion of myeloid progenitors eliminates non-specific binding of MHC-multimers. J Transl Med. 2014 Nov 19;12:317. [Medline: 25406933] [PMC free article: 4243324] [doi: 10.1186/s12967-014-0317-8]

37. Moalic V. Mobilization and collection of peripheral blood stem cells in healthy donors: risks, adverse events and followup. Pathol Biol (Paris). 2013 Apr;61(2):70-4. [Medline: 23199456] [doi: 10.1016/j.patbio.2012.10.003]

\section{To cite this article:}

Yosupov N, Haimov H, Juodzbalys G.

Mobilization, Isolation and Characterization of Stem Cells from Peripheral Blood: a Systematic Review

J Oral Maxillofac Res 2017;8(1):e1

URL: http://www.ejomr.org/JOMR/archives/2017/1/e1/v8n1e1.pdf

doi: $10.5037 /$ jomr.2017.8101

Copyright (C) Yosupov N, Haimov H, Juodzbalys G. Published in the JOURNAL OF ORAL \& MAXILLOFACIAL RESEARCH (http://www.ejomr.org), 31 March 2017.

This is an open-access article, first published in the JOURNAL OF ORAL \& MAXILLOFACIAL RESEARCH, distributed under the terms of the Creative Commons Attribution-Noncommercial-No Derivative Works 3.0 Unported License, which permits unrestricted non-commercial use, distribution, and reproduction in any medium, provided the original work and is properly cited. The copyright, license information and link to the original publication on (http://www.ejomr.org) must be included. 